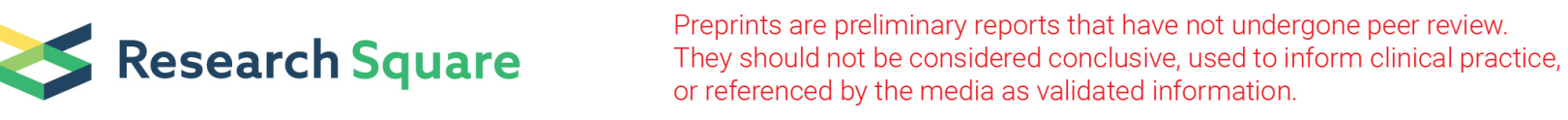

\title{
Surface Chemistry Studies of Emission and Thermal Behaviour of Developed Composites for Building Ceiling Materials
}

JOSEPH OSEKHOGHENE DIRISU ( $\sim$ joseph.dirisu@covenantuniversity.edu.ng )

Covenant University College of Science and Technology https://orcid.org/0000-0003-3310-8854

\section{Sunday Oyedepo}

Covenant University

Ojo Fayomi

Bells University of Technology

\section{Enesi Salawu}

Covenant University

John Oyekunle

Obafemi Awolowo University

\section{Abraham Asere}

Obafemi Awolowo University

Kelvin Efemwenkiekie

Covenant University

\section{Research Article}

Keywords: Flame-retardant, toxic substances, combustion, chemical structure, reinforced materials

Posted Date: May 12th, 2021

DOI: https://doi.org/10.21203/rs.3.rs-495989/v1

License: (c) (i) This work is licensed under a Creative Commons Attribution 4.0 International License. Read Full License 


\section{Abstract}

The emission of harmful elements from burning building ceiling materials and their attendant health effects on inhabitants within the vicinity of the emitted harmful elements is increasingly becoming a source of concern globally. Hence, the need to develop eco-friendly flame-retardant composite materials suitable for house ceiling purposes to forestall unwanted toxic emissions. This work identified the chemical structure of developed composite products and their emission performance during combustion. X-ray Diffraction (XRD) analysis was used for phase quantification and E550 combustion gas analyzer for emission characterization of the developed composites. Thermolyne $950^{\circ} \mathrm{C}$ oven was employed for the combustion analysis of the prepared composite at $500^{\circ} \mathrm{C}$. Quasi negligible $\mathrm{SO}_{2}$ level and $\mathrm{CO}_{2}$ exist; however, $\mathrm{A} 4,{ }_{0.3} \mathrm{Aldr}_{0.23} \mathrm{Cmt}_{0.3} \mathrm{Si}_{0.05} \mathrm{G}_{0.12} \mathrm{CS}$ recorded maximum $\mathrm{CO}$ level, an indication of toxic affluence. The low mass losses of all of the composite materials, especially for $\mathrm{A} 2,{ }_{0.6} \mathrm{Aldr}_{0.34} \mathrm{Cmt}_{0.05} \mathrm{G}_{0.01} \mathrm{OBS}$ retard significantly due to its activities by the retardant constituent. The flame retardant nature of all produced composite was evidenced in their elemental composition, as there was an absence of flammable element and presence of stable insulating compound providing retardance to flame occurrences. These suppressions in the flame inclination of the reinforced materials were noticed within the boundaries of the ceiling crystals from the structural examination. The intermetallic phase from the diffraction intensities showed the presence of a significant second bond interstitial solidphase across the matrix, especially for ${ }_{0.6} \mathrm{Aldr}_{0.34} \mathrm{Cmt}_{0.05} \mathrm{G}_{0.01}$ OBS ceiling material.

\section{Introduction}

The chemical composition of materials tells a lot about its performance and lifecycle [1]. It is seen in equipment and structure where an evidenced corrosion and structural failures are pointers to its microstructural influence [2]. A reduction in structural failure, especially in fire outbreaks, is possible when materials with flame retardant compounds are sought for [3-5]. Flame friendly compounds are primarily $\mathrm{O}_{2}$, nitrogen, water vapour, and $\mathrm{CO}_{2}$. Some materials possess flame inhibiting characteristics as could be seen in the elements that constitute the compounds [6]. These can be found in industrial and agricultural wastes when combined to form a composite for structural applications. Aluminium dross, iron slag, and metal chips from metal processing equipment are examples of industrial wastes with flame inhibiting properties [7]. Aluminium dross, for instance, have $\mathrm{Al}_{2} \mathrm{O}_{3}$ as its primary compound, while $\mathrm{SiO}_{2}, \mathrm{Fe}_{2} \mathrm{O}_{3}$, $\mathrm{MgO}, \mathrm{SO}_{3}, \mathrm{CaO}, \mathrm{TiO}_{2}$, and $\mathrm{Na}_{2} \mathrm{O}$ are its secondary constituents [8]. These compounds are flame retardants in characteristics. Cement possesses a similar composition with aluminium dross, hence, the reason for their partial replacement. Aluminium dross is a pozzolanic industrial waste with the presence aluminium and silica that enables it to form a paste when mixed with water. Outstanding among the elements in cement are lime, calcium oxide, silica, and alumina [9-11].

There also exist agricultural waste materials that are utilized as reinforcement to parent materials for various applications. Examples, among others, are coconut shell, for lightweight construction product, and eggshell, used as reinforcement in aluminium alloy $[12,13]$, while oil beanstalk is being recently employed as an additive to building ceiling [14]. These among many wastes are readily available in the environment, which can be utilized for useful products. The non-combustible nature of base material tends to suppress the flame affluence of reinforcement material. As the demand for eco-friendly and cost-effective materials increases, it is necessary to prepare products that will meet these demands that will be an improvement over the existing ones and compete favourably with them [15].

The aim of the present study was to evaluate the influence of the chemical components of developed building ceiling aluminium dross composite materials on the gaseous emission behaviour during combustion, and their mass loss 
relationship after combustion. This was done in order to establish the suitability of the developed aluminium dross composite materials for house ceiling purposes.

\section{Materials And Methods \\ 2.1 Equipment}

Developed aluminium dross composite materials shown in Appendix A were analyzed for phase quantification using Rigaku SmartLab SE Multipurpose X-ray Diffraction System. The compounds detected at each phase were analyzed to forecast behaviour at the instance of combustion. In a separate experiment, E5500 Portable Industrial Flue Gas \& Emissions Analyzer and Thermolyne oven were combined to determine the combustion, mass loss, and emission behaviours of the specimen. The Labotec Thermolyne oven with operating temperature $+10^{\circ} \mathrm{C}$ to $950^{\circ} \mathrm{C}$ was programmed to a maximum temperature of $500^{\circ} \mathrm{Cfor}$ maximum combustion temperature of ceiling and roof truss. At the same time, the $3.5 \mathrm{~mm}$ probe of the analyzer's hose was inserted through the $6.5 \mathrm{~mm}$ orifice of the thermolyne oven to the ceramic mortar containing the $10 \mathrm{~g}$ pulverized material to capture the gasses evolved during combustion and compared based on EPA/WHO air quality standards. The mass retained was compared to infer their stability after combustion.

\subsection{Source of raw materials}

In this work, aluminium dross, which is the base material, was obtained from Aluminium Rolling Mill (ARM), Ogun Housing Estate, Ota, Ogun State. Ota is located within Longitudes $2^{\circ} 53^{\prime}$ E and $3^{\circ} 14^{\prime}$ E and Latitudes $6^{\circ} 39^{\prime}$ N Southwestern part of Nigeria [16]. Oil beanstalk was obtained from both Oko-Omi in lju, Ogun State, and Covenant University premises. Covenant University is situated within Latitude 6 ${ }^{\circ} 40^{\prime} 30.3^{\prime \prime} \mathrm{N}$ and Longitude3 ${ }^{\circ} 09^{\prime} 46.3^{\prime \prime E}$, Ogun State, Nigeria [17]. Eggshell, coconut shell, carbon graphite, and cement were obtained from the environment and vendors.

\subsection{Sample preparation and production}

Aluminium dross, oil beanstalk, eggshell, and coconut shell were milled to obtain both fine and coarse sizes using grinding milling machine. Aluminium dross and cement were sieved to get a fine particle size of $150 \mu \mathrm{m}$ while eggshell, oil beanstalk, and coconut shell were at $150 \mu \mathrm{m}$ particle size. They were all dried in an oven at $50^{\circ} \mathrm{C}$ for 24 hours. A low-cost mould was 3D printed using MakerBot Replicator at $50 \mathrm{~mm}$ diameter and $10 \mathrm{~mm}$ thickness for the production of the composite materials.

\subsection{Surface Chemistry analysis of composite using Rigaku X-ray diffractometer}

Accurately weighed $20 \mathrm{~g}$ of milled samples were prepared and labelled for easy identification. It was placed in a sample holder. The powder was pressed against the glass slide to stick well. These were marked and labelled accordingly. The marked number was inputted in the XRD machine. Before this, the XRD was calibrated using a silicon standard. After that, the line of the best fit was plotted, and the peak of the XRD can be identified. The sample name was saved with a file ID. This process was repeated for the other samples. The equipment for XRD is shown in Fig. 1.

\subsection{Combustion and emission procedure with E550 emission analyzer and thermolyne oven}


The advanced equipment employed for this research are E5500 emission analyzer, and Thermolyne Oven. An equal $10 \mathrm{~g}$ of pulverized composite sample was measured using the weighing balance and labelled for easy identification. Each labelled sample, in turn, was poured into a ceramic mortar capable of withstanding temperatures in the range of $1000^{\circ} \mathrm{C}-1600^{\circ} \mathrm{C}$. The ceramic mortar was positioned in the $8 \mathrm{~mm}$ diameter orifice of Thermolyne furnace with $950^{\circ} \mathrm{C}$ temperature capacity. The gasses were to escape from the orifice, which is typical of exit spots during fire inferno. The equipment was switched on, and the temperature was set to $500^{\circ} \mathrm{C}$ to represent the maximum combustion temperature of ceiling and roof trusses during fire outbreak.

The analyzer's probe was inserted into the Thermolyne furnace, as shown in Fig. 2. It has a diameter of $6.2 \mathrm{~mm}$ and a length $3 \mathrm{~m}$. It passes through the orifice to the tip of the ceramic mortar to detect both emissions and temperature during combustion.

\section{Results And Discussion}

This section presents the surface chemistry analysis of the developed ceiling materials. Compounds that are likely to be emitted during the performance and combustion processes were identified along with compounds with binding capability and possible noxious characteristics. For an easy identification and discussion, the samples have been coded A1, A2, A3 and A4 in place of ${ }_{0.6} \mathrm{Aldr}_{0.3} \mathrm{Cmt}_{0.05} \mathrm{G}_{0.05} \mathrm{OBS},{ }_{0.6} \mathrm{Aldr}_{0.34} \mathrm{Cmt}_{0.05} \mathrm{G}_{0.01} \mathrm{OBS}, 0.6 \mathrm{Aldr}_{0.32} \mathrm{Cmt}_{0.05} \mathrm{G}_{0.03} \mathrm{UES}_{\text {, }}$ and ${ }_{0.3} \mathrm{Aldr}_{0.23} \mathrm{Cmt}_{0.3} \mathrm{Si}_{0.05} \mathrm{G}_{0.12} \mathrm{CS}$. Aldr is Aluminium dross, $\mathrm{Cmt}$ is Cement, $\mathbf{S i}$ is Silicate, $\mathbf{G}$ is Carbon Graphite, OBS is Oil Bean Stalk, UES is Uncarbonized Egg Shell, and CS is Coconut Shell. Figure 3 to Fig. 6 show the biophase and triphase quantification of developed ceiling composite samples and their peak at a different diffracted angle.

Eight phases were evidenced by the qualitative XRD pattern at Braga angles of $18.6^{0}, 23.2^{0}, 29.5^{0}, 37.8^{0}, 43.4^{0}, 48.6^{0}$, $57.6^{0}$, and $60.8^{0}$ as shown in Fig. 3. The constitutive materials for $\mathrm{A} 1$ are aluminium dross $60 \%$, cement $30 \%$, carbon graphite $5 \%$ and oil beanstalk $5 \%$. The materials had inherent elements that could likely cause diffraction when bombarded by an X-ray.

The substances present were silicon oxide, calcio-olivine, cordierite ferroan, kyanite, and dialuminum silicate oxide. It confirms that it is a heterogeneous material with aluminium and cement having dominance. The material is crystal in nature with the lattice structure of body-centred cubic (BCC), face-centred cubic (FCC), and hexagonal cubic packing (HCP) arrangements, mainly present. The crystalline nature is characteristic of cement, which is partly present in this composite [18]. The grain size of the materials is $0.234 \mathrm{~nm}$. The presence of elements such as magnesium, aluminium, silicon, and calcium make the compound overall non-flammable at the instance of combustion, as revealed by earlier workers $[19,20]$. Oxygen contributes to negligible weight loss when subjected to burning. Its minimal concentration is significant to flame spread inhibition [21, 22]. $\mathrm{Mg}_{2}\left(\mathrm{Al}_{4} \mathrm{Si}_{5} \mathrm{O}_{18}\right)$ is also called Cordierite, or ferroan, which is substantial at peak 1 as shown in Fig. 3.

At phase 2, the substances present were calico-olivine, cordierite ferroan, dicalcium diiron (III) oxide, kyanite, and dialuminum silicate oxide. $\mathrm{Ca}_{2} \mathrm{Fe}_{2} \mathrm{O}_{5}$ is significant as it is deposited at this peak. Calcium olivine is a natural mineral, an orthosilicate type that is usually found at the earth subsurface. It is orthorhombic in its crystal system [23]. Its melting temperature is unusually high $\approx 2000^{\circ} \mathrm{C}$ [24] with a high covalent bond [25]. This makes it a contributory flame retardant compound. Dialuminium silicate is a naturally occurring soil constituent, usually called clay that is composed of trace metal oxide and anhydrous aluminium silicate. The constituent element that forms the compound reveals it is partly covalent and partly ionic, according to earlier reports [26]. The bond of these elements forms a barrier for oxygen to diffuse, thus raising the thermal effusivity and flame retardant characteristics of the developed 
composite ceiling materials. The minuscule weight loss was due to the flammable additive in the composite [27]. Kyanite is a polymorph that is triclinic in the crystal system and crystal bladed or tabular in morphology [28]. Two aluminium atoms suggest that one is more ionically bonded in one and covalently bonded in the other [29]. Silicone is present in the compound, which is a flame retardant indicator.

A closer look at peak 3 revealed that the substances present were silicon oxide, calcium olivine and cordierite ferroan. However, $\mathrm{Ca}_{2}\left(\mathrm{SiO}_{4}\right)$ called Calcio-olivine is deposited, as shown in Fig. 3. The bond interaction of silicon inhibits the thermal conductivity nature of the metallic element, such as Al and $\mathrm{Mg}$ and flame fuel nature of oxygen, which is present in most of the compounds [27]. Once oxygen is suppressed, there isn't room for successful combustion, which is a desirable result in ceiling composites. At peak 4, the elements present are corundum, calico-olivine, cordierite ferroan, dicalcium diiron (III) oxide, kyanite, and dialuminum silicate oxide. $\mathrm{However}_{2} \mathrm{Al}_{2}\left(\mathrm{SiO}_{4}\right) \mathrm{O}$ was placed at this peak. The absence of carbon as present in the preliminary materials such as aluminium dross, cement, oil bean husk, and carbon graphite were probably due to its deficient composition and low energy when zapped with a beam of X-ray.

At peak three-phase, substances present at this peak were corundum, cordierite ferroan, and dicalcium diiron (III) oxide. $\mathrm{Al}_{2} \mathrm{O}_{3}$ called corundum was deposited at this peak. The average interplanar spacing Fig...is $0.49 \mathrm{~nm}$. Investigating XRD Analysis of $\mathrm{A} 2{ }_{, 0.6} \mathrm{Aldr}_{0.34} \mathrm{Cmt}_{0.05} \mathrm{G}_{0.01} \mathrm{OBS}$, the peak where the compounds are deposited is represented in numbers in Fig. 4, which shows the presence of binding elements and compounds that are flame retardant in composition. Also, for XRD Analysis of $A 3,0.6 \mathrm{Aldr}_{0.32} \mathrm{Cmt}_{0.05} \mathrm{G}_{0.03} \mathrm{UES}$, the peak where the compounds were deposited is represented in Fig. 5. The compounds exhibited flame retardance and an absence of harmful substances as evidenced in the emission behaviour following its combustion. During the XRD analysis of $\mathrm{A} 4,0.3 \mathrm{Aldr}_{0.23} \mathrm{Cmt}_{0.3} \mathrm{Si}_{0.05} \mathrm{G}_{0.12} \mathrm{CS}$, the peak where the substances were deposited is represented in numbers in Fig. 6 . The elements calcium and magnesium (alkaline earth metals), and aluminium are not flammable at the operating temperature. Their presence is also evidence of the excellent bond of the composite. The presence of silicon also provides a shield from flame penetration, which in the overall will retard a significantly flame spread.

\subsection{Concentration of Gas Emission and Temperature of Emission @ $0.01 \mathrm{~kg}$ for all Samples}

\subsubsection{A1: $0.6 \mathrm{Aldr}_{0.3} \mathrm{Cmt}_{0.05} \mathrm{G}_{0.05} \mathrm{OBS}$}

Tables 1-4 present the emission characteristics of selected samples A1-A4 which give the values of the noxious elements emitted in part per million (ppm). The emission detection or non-detection of noxious substances is in conformity to international standards and would help to determine the suitability or not of the developed composite materials for ceiling purposes.

From Table 1 at a preset temperature of $500^{\circ} \mathrm{C}$ in the muffler furnace, it took 24 minutes to reach maximum temperature. Effervescence evolved at 12 minutes for $\mathrm{CO}_{2}$ and 11 minutes for NO. The highest $\mathrm{CO}$ value (2265 ppm) occurred at time 19 seconds at temperature of $456^{\circ} \mathrm{C}$. At this the point, the value of $\mathrm{CO}_{2}$ was constant at $0.5 \mathrm{ppm}$, and $\mathrm{O}_{2}$ was also steady at $19.8 \mathrm{ppm}$. Reduction in $\mathrm{O}_{2}$ at $19.8 \mathrm{ppm}$ at time (18-24) minutes enabled $\mathrm{CO}_{2}$ to be maximum and constant at this range while there was a significant uptrend in the values of $\mathrm{NO} / \mathrm{NO}_{\mathrm{x}}$ which came to a peak at $49 \mathrm{ppm}$. A completely enclosed apartment during a fire outbreak will reduce the $\mathrm{O}_{2}$ level, causing the 
significant rise and diffusion of $\mathrm{CO}_{2}$ and nitrogen compounds. The gas $\mathrm{SO}_{2}$ was not detected at any point during the period of burning. This observation was particularly connected to the elemental nature of the understudied ceiling composite sample A1. The values of the noxious nitrogen gas increased as the temperature and time increased, indicating that its diffusion was temperature-dependent.

\subsubsection{A2: ${ }_{0.6} \mathrm{Aldr}_{0.34} \mathrm{Cmt}_{0.05} \mathrm{G}_{0.01} \mathrm{OBS}$}

From Table 2, the temperature value of $500^{\circ} \mathrm{C}$ was reached at 37 minutes, while $300^{\circ} \mathrm{C}$ was the temperature to start up the momentum of $\mathrm{CO}$ gas at $54 \mathrm{ppm}$. The reluctance up to this point is connected to the bond force of the atomic structure of the ceiling composite. However, $\mathrm{SO}_{2}$ is detected at a maximum of $3 \mathrm{ppm}$ and discontinued when $\mathrm{CO}$ started. $\mathrm{SO}_{2}$ presence is linked to visible flame rich in $\mathrm{O}_{2}$ and in absence of $\mathrm{CO}$. Maximum values of NO/NOx were observed at maximum temperature, minimum $\mathrm{O}_{2}$ and maximum $\mathrm{CO}_{2}$.

\subsubsection{A3: ${ }_{0.6} \mathrm{Aldr}_{0.32} \mathrm{Cmt}_{0.05} \mathrm{G}_{0.03} \mathrm{UES}$}

From Table 3, 45 minutes elapsed before a temperature of $500^{\circ} \mathrm{C}$ was attained. Nitrogen compounds at $2 \mathrm{ppm}$ and $295^{\circ} \mathrm{C}$ were not detected until 25 minutes. At this temperature, the charring of modern protective clothing fabrics begins [30]. $\mathrm{CO}_{2}$ level was generally low at $0.1 \mathrm{ppm}$, which is desirable. CO maximum, $1281 \mathrm{ppm}$, was reached at 42 minutes and experienced a stable rise with temperature. Maximum NO/NOx was $46 \mathrm{ppm}$ at maximum temperature. This observation was expected and well confirmed by earlier workers [31] that nitrogen oxide increases at an increasing temperature.

\subsubsection{A4: ${ }_{0.3} \mathrm{Aldr}_{0.23} \mathrm{Cmt}_{0.3} \mathrm{Si}_{0.05} \mathrm{G}_{0.12} \mathrm{CS}$}

From developed ${ }_{0.3} \mathrm{Aldr}_{0.23} \mathrm{cmt}_{0.3} \mathrm{Si}_{0.05} \mathrm{G}_{0.12} \mathrm{CS}$, it took 37 minutes to attain the preset temperature of $500^{\circ} \mathrm{C}$, as shown in Table 4. The inherent thermal inertia was probably responsible for the reluctance in heat dissipation as evidenced by the long-time extension compared to that of $A 1$. The variation in material percentage mixture is also a causative feature. The peak value of $\mathrm{CO}$ at $5236 \mathrm{ppm}$ came to fore at 19 minutes. At this point, concentration mass transfer of CO was maximum and undulated before and after this value due to collision with other molecules and ripple temperature. The nitrogen compound was at zero levels up to 16 minutes. The reason might be due to the source of combustion and the probable presence of nitrogen and oxygen in the elemental buildup of this ceiling composite. Values of $\mathrm{NO} / \mathrm{NO}_{\mathrm{x}}$ increased due to a corresponding temperature rise. It came to a maximum at $38 \mathrm{ppm}$ at maximum temperature of $500^{\circ} \mathrm{C}$. Maximum $\mathrm{O}_{2}$ at $21.0 \mathrm{ppm}$ established null $\mathrm{CO}_{2}(0.0 \mathrm{ppm})$. The presence of $\mathrm{CO}$ reduces the survival chances of occupants due to the low oxygen level. Low $\mathrm{O}_{2}$ permits emission of other noxious gases such as $\mathrm{NO} / \mathrm{NO}_{\mathrm{x}}, \mathrm{CO}_{2}$, which contributes to discomfort at the fire outbreak. Emission especially has drastically reduced, and air quality has improved over the last four decades due to close monitoring by international bodies such as World Health Organizations (WHO) and European Union (EU) as confirmed by previous studies [32].

Table 1: A1, $0.6 \mathrm{Aldr}_{0.3} \mathrm{Cmt}_{0.05} \mathrm{G}_{0.05} \mathrm{OBS}$ 


\begin{tabular}{|c|c|c|c|c|c|c|c|c|c|}
\hline $\begin{array}{l}\text { Time } \\
(\min )\end{array}$ & $\mathrm{T}_{\mathrm{g}}\left({ }^{\circ} \mathrm{C}\right)$ & $\begin{array}{l}\text { Temp. } \\
\left({ }^{\circ} \mathrm{C}\right)\end{array}$ & $\begin{array}{l}\mathrm{CO} \\
(\mathrm{ppm})\end{array}$ & $\mathrm{O}_{2}(\mathrm{ppm})$ & $\mathrm{CO}_{2}(\mathrm{ppm})$ & $\mathrm{NO}(\mathrm{ppm})$ & $\mathrm{NO}_{\mathbf{X}}(\mathrm{ppm})$ & $\mathrm{NO}_{2}(\mathrm{ppm})$ & $\mathrm{SO}_{2}(\mathrm{ppm})$ \\
\hline 1 & 53 & 233 & 33 & 20.8 & 0 & 0 & 0 & 0 & 0 \\
\hline 2 & 92 & 273 & 37 & 20.8 & 0 & 0 & 0 & 0 & 0 \\
\hline 3 & 128 & 287 & 40 & 20.8 & 0 & 0 & 0 & 0 & 0 \\
\hline 4 & 142 & 294 & 41 & 20.8 & 0 & 0 & 0 & 0 & 0 \\
\hline 5 & 170 & 305 & 46 & 20.8 & 0 & 0 & 0 & 0 & 0 \\
\hline 6 & 201 & 317 & 59 & 20.7 & 0 & 0 & 0 & 0 & 0 \\
\hline 7 & 236 & 331 & 87 & 20.7 & 0 & 0 & 0 & 0 & 0 \\
\hline 8 & 258 & 341 & 178 & 20.6 & 0 & 0 & 0 & 0 & 0 \\
\hline 9 & 282 & 352 & 324 & 20.5 & 0 & 0 & 0 & 0 & 0 \\
\hline 10 & 305 & 363 & 603 & 20.5 & 0 & 0 & 0 & 0 & 0 \\
\hline 11 & 329 & 373 & 877 & 20.4 & 0 & 3 & 3 & 0 & 0 \\
\hline 12 & 356 & 386 & 1211 & 20.3 & 0.2 & 3 & 3 & 0 & 0 \\
\hline 13 & 374 & 395 & 1213 & 20.4 & 0.2 & 3 & 3 & 0 & 0 \\
\hline 14 & 391 & 406 & 1333 & 20.3 & 0.2 & 4 & 4 & 0 & 0 \\
\hline 15 & 407 & 416 & 1458 & 20.2 & 0.3 & 4 & 4 & 0 & 0 \\
\hline 16 & 423 & 427 & 1798 & 20.0 & 0.4 & 6 & 6 & 0 & 0 \\
\hline 17 & 437 & 436 & 1201 & 19.9 & 0.4 & 7 & 7 & 0 & 0 \\
\hline 18 & 453 & 446 & 1217 & 19.8 & 0.5 & 10 & 10 & 0 & 0 \\
\hline 19 & 465 & 456 & 2265 & 19.8 & 0.5 & 13 & 13 & 0 & 0 \\
\hline 20 & 479 & 465 & 2212 & 19.8 & 0.5 & 16 & 16 & 0 & 0 \\
\hline 21 & 494 & 477 & 2120 & 19.8 & 0.5 & 23 & 23 & 0 & 0 \\
\hline 22 & 503 & 484 & 2054 & 19.8 & 0.5 & 30 & 30 & 0 & 0 \\
\hline 23 & 515 & 494 & 1951 & 19.8 & 0.5 & 40 & 40 & 0 & 0 \\
\hline 24 & 527 & 500 & 1828 & 19.8 & 0.5 & 49 & 49 & 0 & 0 \\
\hline
\end{tabular}

Table 2: $\mathrm{A} 2,0.6 \mathrm{Aldr}_{0.34} \mathrm{Cmt}_{0.05} \mathrm{G}_{0.01}$ OBS 


\begin{tabular}{|c|c|c|c|c|c|c|c|c|c|}
\hline $\begin{array}{l}\text { Time } \\
(\min )\end{array}$ & $\begin{array}{l}\text { Temp. } \\
\left({ }^{\circ} \mathrm{C}\right)\end{array}$ & $\begin{array}{l}\mathrm{Tg} \\
\left({ }^{\circ} \mathrm{C}\right)\end{array}$ & $\begin{array}{l}\mathrm{co} \\
(\mathrm{ppm})\end{array}$ & $\mathrm{O}_{2}(\mathrm{ppm})$ & $\mathrm{CO}_{2}(\mathrm{ppm})$ & NO(ppm) & $\mathrm{NO}_{\mathbf{x}}(\mathrm{ppm})$ & $\mathrm{NO}_{2}(\mathrm{ppm})$ & $\mathrm{SO}_{2}(\mathrm{ppm})$ \\
\hline 1 & 103 & 47 & 0 & 20.7 & 0.3 & 0 & 0 & 0 & 3 \\
\hline 2 & 130 & 55 & 0 & 20.7 & 0.3 & 0 & 0 & 0 & 3 \\
\hline 3 & 143 & 67 & 0 & 20.6 & 0.2 & 0 & 0 & 0 & 3 \\
\hline 4 & 155 & 79 & 0 & 20.7 & 0.2 & 0 & 0 & 0 & 3 \\
\hline 5 & 167 & 91 & 0 & 20.7 & 0.2 & 0 & 0 & 0 & 3 \\
\hline 6 & 179 & 104 & 0 & 20.6 & 0.3 & 0 & 0 & 0 & 3 \\
\hline 7 & 190 & 117 & 0 & 20.7 & 0.2 & 0 & 0 & 0 & 2 \\
\hline 8 & 201 & 129 & 0 & 20.7 & 0.2 & 0 & 0 & 0 & 3 \\
\hline 9 & 212 & 144 & 0 & 20.7 & 0.2 & 0 & 0 & 0 & 3 \\
\hline 10 & 224 & 160 & 0 & 20.7 & 0.2 & 0 & 0 & 0 & 2 \\
\hline 11 & 235 & 176 & 0 & 20.7 & 0.2 & 0 & 0 & 0 & 2 \\
\hline 12 & 246 & 192 & 0 & 20.7 & 0.3 & 0 & 0 & 0 & 2 \\
\hline 13 & 258 & 209 & 0 & 20.7 & 0.3 & 0 & 0 & 0 & 2 \\
\hline 14 & 269 & 224 & 0 & 20.7 & 0.3 & 0 & 0 & 0 & 2 \\
\hline 15 & 279 & 240 & 0 & 20.6 & 0.3 & 0 & 0 & 0 & 2 \\
\hline 16 & 290 & 256 & 0 & 20.6 & 0.3 & 0 & 0 & 0 & 2 \\
\hline 17 & 300 & 270 & 54 & 20.5 & 0.3 & 2 & 2 & 0 & 0 \\
\hline 18 & 312 & 283 & 191 & 20.5 & 0.5 & 2 & 2 & 0 & 0 \\
\hline 19 & 322 & 297 & 348 & 20.4 & 0.5 & 3 & 3 & 0 & 0 \\
\hline 20 & 333 & 313 & 558 & 20.4 & 0.6 & 4 & 4 & 0 & 0 \\
\hline 21 & 344 & 329 & 809 & 20.3 & 0.6 & 5 & 5 & 0 & 0 \\
\hline 22 & 354 & 345 & 1056 & 20.3 & 0.8 & 6 & 6 & 0 & 0 \\
\hline 23 & 364 & 360 & 1196 & 20.2 & 0.8 & 6 & 6 & 0 & 0 \\
\hline 24 & 374 & 374 & 1320 & 20.2 & 0.9 & 6 & 6 & 0 & 0 \\
\hline 25 & 384 & 386 & 1305 & 20.1 & 0.9 & 5 & 5 & 0 & 0 \\
\hline 26 & 395 & 399 & 1250 & 20.1 & 0.8 & 5 & 5 & 0 & 0 \\
\hline 27 & 405 & 412 & 1236 & 20.1 & 1.0 & 5 & 5 & 0 & 0 \\
\hline 28 & 415 & 424 & 1308 & 20.0 & 1.0 & 5 & 5 & 0 & 0 \\
\hline 29 & 425 & 437 & 1423 & 19.9 & 1.2 & 6 & 6 & 0 & 0 \\
\hline 30 & 435 & 450 & 1525 & 19.8 & 1.3 & 8 & 8 & 0 & 0 \\
\hline 31 & 445 & 462 & 1564 & 19.7 & 1.4 & 10 & 10 & 0 & 0 \\
\hline
\end{tabular}




\begin{tabular}{|llllllllll|}
32 & 454 & 476 & 1616 & 19.7 & 1.4 & 13 & 13 & 0 & 0 \\
\hline 33 & 464 & 489 & 1699 & 19.7 & 1.5 & 16 & 16 & 0 & 0 \\
34 & 473 & 501 & 1740 & 19.7 & 1.5 & 20 & 20 & 0 & 0 \\
35 & 483 & 511 & 1712 & 19.7 & 1.5 & 27 & 27 & 0 & 0 \\
\hline 36 & 492 & 521 & 1608 & 19.7 & 1.4 & 34 & 34 & 0 & 0 \\
37 & 500 & 533 & 1444 & 19.8 & 1.4 & 44 & 44 & 0 & 0 \\
\hline
\end{tabular}

Table 3: A3, ${ }_{0.6} \mathrm{Aldr}_{0.32} \mathrm{Cmt}_{0.05} \mathrm{G}_{0.03} \mathrm{UES}$ 


\begin{tabular}{|c|c|c|c|c|c|c|c|c|c|}
\hline $\begin{array}{l}\text { Time } \\
\text { (min) }\end{array}$ & $\begin{array}{l}\text { Temp. } \\
\left({ }^{\circ} \mathrm{C}\right)\end{array}$ & $\begin{array}{l}\mathrm{Tg} \\
\left({ }^{\circ} \mathrm{C}\right)\end{array}$ & $\begin{array}{l}\mathrm{CO} \\
(\mathrm{ppm})\end{array}$ & $\mathrm{O}_{2}(\mathrm{ppm})$ & $\mathrm{CO}_{2}(\mathrm{ppm})$ & $\mathrm{NO}(\mathrm{ppm})$ & $\mathrm{NO}_{x}(\mathrm{ppm})$ & $\mathrm{NO}_{2}(\mathrm{ppm})$ & $\mathrm{SO}_{2}(\mathrm{ppm})$ \\
\hline 1 & 34 & 25 & 10 & 20.8 & 0.1 & 0 & 0 & 0 & 0 \\
\hline 2 & 36 & 26 & 12 & 20.8 & 0.1 & 0 & 0 & 0 & 0 \\
\hline 3 & 44 & 28 & 15 & 20.8 & 0.1 & 0 & 0 & 0 & 0 \\
\hline 4 & 53 & 31 & 17 & 20.8 & 0.1 & 0 & 0 & 0 & 0 \\
\hline 5 & 63 & 36 & 20 & 20.8 & 0.1 & 0 & 0 & 0 & 0 \\
\hline 6 & 74 & 43 & 21 & 20.8 & 0.1 & 0 & 0 & 0 & 0 \\
\hline 7 & 85 & 51 & 22 & 20.8 & 0.1 & 0 & 0 & 0 & 0 \\
\hline 8 & 97 & 60 & 24 & 20.8 & 0.1 & 0 & 0 & 0 & 0 \\
\hline 9 & 108 & 70 & 27 & 20.8 & 0.2 & 0 & 0 & 0 & 0 \\
\hline 10 & 120 & 80 & 27 & 20.8 & 0.1 & 0 & 0 & 0 & 0 \\
\hline 11 & 132 & 92 & 31 & 20.8 & 0.1 & 0 & 0 & 0 & 0 \\
\hline 12 & 144 & 104 & 29 & 20.8 & 0.1 & 0 & 0 & 0 & 0 \\
\hline 13 & 156 & 117 & 32 & 20.8 & 0.1 & 0 & 0 & 0 & 0 \\
\hline 14 & 168 & 129 & 33 & 20.8 & 0.1 & 0 & 0 & 0 & 0 \\
\hline 15 & 180 & 142 & 34 & 20.8 & 0.1 & 0 & 0 & 0 & 0 \\
\hline 16 & 192 & 156 & 35 & 20.8 & 0.1 & 0 & 0 & 0 & 0 \\
\hline 17 & 204 & 170 & 36 & 20.8 & 0.1 & 0 & 0 & 0 & 0 \\
\hline 18 & 215 & 184 & 36 & 20.8 & 0.1 & 0 & 0 & 0 & 0 \\
\hline 19 & 226 & 198 & 42 & 20.8 & 0.1 & 0 & 0 & 0 & 0 \\
\hline 20 & 237 & 213 & 42 & 20.7 & 0.1 & 0 & 0 & 0 & 0 \\
\hline 21 & 249 & 229 & 53 & 20.8 & 0.1 & 0 & 0 & 0 & 0 \\
\hline 22 & 260 & 243 & 73 & 20.8 & 0.1 & 0 & 0 & 0 & 0 \\
\hline 23 & 272 & 258 & 103 & 20.7 & 0.2 & 0 & 0 & 0 & 0 \\
\hline 24 & 284 & 272 & 144 & 20.7 & 0.2 & 0 & 0 & 0 & 0 \\
\hline 25 & 295 & 286 & 212 & 20.7 & 0.2 & 2 & 2 & 0 & 0 \\
\hline 26 & 306 & 299 & 313 & 20.7 & 0.3 & 2 & 2 & 0 & 0 \\
\hline 27 & 316 & 313 & 494 & 20.6 & 0.4 & 3 & 3 & 0 & 0 \\
\hline 28 & 327 & 327 & 645 & 20.5 & 0.4 & 4 & 4 & 0 & 0 \\
\hline 29 & 338 & 342 & 856 & 20.4 & 0.5 & 4 & 4 & 0 & 0 \\
\hline 30 & 349 & 358 & 990 & 20.4 & 0.5 & 4 & 4 & 0 & 0 \\
\hline 31 & 359 & 371 & 1113 & 20.3 & 0.6 & 3 & 3 & 0 & 0 \\
\hline
\end{tabular}




\begin{tabular}{|llllllllll|}
32 & 369 & 382 & 1219 & 20.3 & 0.7 & 4 & 4 & 0 & 0 \\
\hline 33 & 380 & 393 & 1056 & 20.4 & 0.7 & 3 & 3 & 0 & 0 \\
34 & 390 & 405 & 1039 & 20.3 & 0.7 & 4 & 4 & 0 & 0 \\
\hline 35 & 401 & 416 & 1062 & 20.3 & 0.7 & 5 & 5 & 0 & 0 \\
\hline 36 & 411 & 427 & 1113 & 20.2 & 0.8 & 6 & 6 & 0 & 0 \\
\hline 37 & 421 & 439 & 1158 & 20.1 & 0.9 & 8 & 8 & 0 & 0 \\
\hline 38 & 431 & 450 & 1187 & 20.0 & 1.0 & 10 & 10 & 0 & 0 \\
\hline 39 & 441 & 462 & 1207 & 20.0 & 1.1 & 13 & 13 & 0 & 0 \\
\hline 40 & 451 & 474 & 1232 & 20.0 & 1.1 & 16 & 16 & 0 & 0 \\
\hline 41 & 461 & 485 & 1267 & 20.0 & 1.0 & 20 & 20 & 0 & 0 \\
\hline 42 & 471 & 496 & 1281 & 20.0 & 1.0 & 24 & 24 & 0 & 0 \\
\hline 43 & 480 & 505 & 1249 & 20.0 & 1.0 & 30 & 30 & 0 & 0 \\
\hline 44 & 489 & 514 & 1174 & 20.0 & 1.0 & 38 & 38 & 0 & 0 \\
\hline 45 & 500 & 524 & 1076 & 20.0 & 1.0 & 46 & 46 & 0 & 0 \\
\hline
\end{tabular}

Table 4: A4, $0.3 \mathrm{Aldr}_{0.23} \mathrm{Cmt}_{0.3} \mathrm{Si}_{0.05} \mathrm{G}_{0.12} \mathrm{CS}$ 


\begin{tabular}{|c|c|c|c|c|c|c|c|c|c|}
\hline $\begin{array}{l}\text { Time } \\
(\min )\end{array}$ & $\begin{array}{l}\text { Temp. } \\
\left({ }^{\circ} \mathrm{C}\right)\end{array}$ & $\begin{array}{l}\mathrm{Tg} \\
\left({ }^{\circ} \mathrm{C}\right)\end{array}$ & $\begin{array}{l}\mathrm{CO} \\
(\mathrm{ppm})\end{array}$ & $\mathrm{O}_{2}(\mathrm{ppm})$ & $\mathrm{CO}_{2}(\mathrm{ppm})$ & NO(ppm) & $\mathrm{NO}_{\mathrm{x}}(\mathrm{ppm})$ & $\mathrm{NO}_{2}(\mathrm{ppm})$ & $\mathrm{SO}_{2}(\mathrm{ppm})$ \\
\hline 1 & 103 & 35 & 0 & 21.0 & 0 & 0 & 0 & 0 & 0 \\
\hline 2 & 134 & 49 & 0 & 21.0 & 0 & 0 & 0 & 0 & 0 \\
\hline 3 & 148 & 64 & 0 & 21.0 & 0 & 0 & 0 & 0 & 0 \\
\hline 4 & 160 & 77 & 0 & 21.0 & 0 & 0 & 0 & 0 & 0 \\
\hline 5 & 172 & 89 & 0 & 21.0 & 0 & 0 & 0 & 0 & 0 \\
\hline 6 & 183 & 101 & 0 & 20.9 & 0 & 0 & 0 & 0 & 0 \\
\hline 7 & 194 & 114 & 0 & 21.0 & 0 & 0 & 0 & 0 & 0 \\
\hline 8 & 206 & 128 & 0 & 20.9 & 0 & 0 & 0 & 0 & 0 \\
\hline 9 & 217 & 144 & 0 & 20.9 & 0 & 0 & 0 & 0 & 0 \\
\hline 10 & 229 & 160 & 4 & 20.9 & 0 & 0 & 0 & 0 & 0 \\
\hline 11 & 241 & 179 & 12 & 20.9 & 0 & 0 & 0 & 0 & 0 \\
\hline 12 & 252 & 195 & 42 & 20.9 & 0 & 0 & 0 & 0 & 0 \\
\hline 13 & 263 & 213 & 144 & 20.9 & 0 & 0 & 0 & 0 & 0 \\
\hline 14 & 275 & 232 & 366 & 20.9 & 0 & 0 & 0 & 0 & 0 \\
\hline 15 & 285 & 251 & 744 & 20.7 & 0.3 & 0 & 0 & 0 & 0 \\
\hline 16 & 296 & 270 & 1412 & 20.5 & 0.5 & 2 & 2 & 0 & 0 \\
\hline 17 & 307 & 290 & 2524 & 20.2 & 0.9 & 6 & 6 & 0 & 0 \\
\hline 18 & 318 & 310 & 4304 & 20.0 & 1.1 & 16 & 16 & 0 & 0 \\
\hline 19 & 329 & 331 & 5236 & 20.0 & 1.0 & 34 & 34 & 0 & 0 \\
\hline 20 & 339 & 350 & 4163 & 20.3 & 0.6 & 42 & 42 & 0 & 0 \\
\hline 21 & 349 & 367 & 3541 & 20.4 & 0.5 & 35 & 35 & 0 & 0 \\
\hline 22 & 360 & 382 & 3857 & 20.4 & 0.5 & 30 & 30 & 0 & 0 \\
\hline 23 & 371 & 393 & 3885 & 20.4 & 0.5 & 25 & 25 & 0 & 0 \\
\hline 24 & 381 & 406 & 3819 & 20.4 & 0.5 & 20 & 20 & 0 & 0 \\
\hline 25 & 391 & 419 & 3624 & 20.4 & 0.6 & 17 & 17 & 0 & 0 \\
\hline 26 & 402 & 431 & 3402 & 20.4 & 0.6 & 15 & 15 & 0 & 0 \\
\hline 27 & 412 & 443 & 3229 & 20.4 & 0.6 & 14 & 14 & 0 & 0 \\
\hline 28 & 422 & 455 & 3055 & 20.3 & 0.6 & 14 & 14 & 0 & 0 \\
\hline 29 & 432 & 464 & 2878 & 20.3 & 0.7 & 15 & 15 & 0 & 0 \\
\hline 30 & 442 & 476 & 2720 & 20.3 & 0.6 & 16 & 16 & 0 & 0 \\
\hline 31 & 452 & 486 & 2591 & 20.3 & 0.7 & 19 & 19 & 0 & 0 \\
\hline
\end{tabular}




\begin{tabular}{|llllllllll|}
32 & 461 & 496 & 2477 & 20.3 & 0.7 & 23 & 23 & 0 & 0 \\
33 & 470 & 505 & 2396 & 20.3 & 0.7 & 27 & 27 & 0 & 0 \\
34 & 480 & 514 & 2369 & 20.2 & 0.8 & 31 & 31 & 0 & 0 \\
35 & 490 & 523 & 2333 & 20.2 & 0.7 & 33 & 33 & 0 & 0 \\
\hline 36 & 498 & 534 & 2310 & 20.3 & 0.7 & 37 & 37 & 0 & 0 \\
37 & 500 & 537 & 2313 & 20.3 & 0.7 & 38 & 38 & 0 & 0 \\
\hline
\end{tabular}

The cooling rate during the combustion-emission experiment was obtained from the cooling gradient to time. The cooling gradient is shown in Figs. 7-10. The comparison among the cooling rates of the samples is shown in Fig. 11. The thickness of the ceiling sample directly affected the cross-sectional area available for heat to flow, which in turn governed the cooling rate of the sample location. The temperature decreased much slower and, in some instances, attained constant values as it approached the room temperature. Samples A2 and A4 had the highest cooling rate at $1.86^{\circ} \mathrm{C} / \mathrm{min}$, while sample $\mathrm{A} 1 \mathrm{had}$ the lowest cooling rate at $1.79^{\circ} \mathrm{C} / \mathrm{min}$. The cooling rate is dependent on the nature of the microstructure and composite material composition that readily releases heat or vice versa. It is important to note that the structure of a metal composite is determined by the thermal cooling history that leads to the final product [33]. Cooling history gives an insight to the crystallinity of polymer composites [34]. An investigator [35] reasoned that there is a strong correlation between cooling rate and crystallinity of carbon fibre composites, hence the tendency of cooling rate to alter the performance of carbon fibre/polyether ether ketone composites becomes pertinent.

\subsubsection{Comparison mass retained after combustion}

The materials in Fig. 12 showed significant mass conservation after combustion with little mass loss in the range of 1.8-2.41 g. The base materials and binders such as aluminium dross, cement, silicate, and carbon graphite changed slightly in physical appearance due to trace moisture in their composition. Reinforcement materials such as coconut shells, oil beanstalk, and eggshell degraded due to their flammability tendencies. Composite material A2 was most stable after combustion with $1.8 \mathrm{~g}$ loss of material compared to other materials due to the oil beanstalk reinforcement and residual moisture in the composite.

\section{Conclusion}

This paper investigated the influence of chemical composition on the emission and thermal weight loss of developed aluminium dross ceiling tiles. XRD was employed for phase quantification, Emission Gas Analyzer for emission analysis, Thermolyne Oven for combustion and mass loss investigation of the developed samples. It was established that there was the presence of flame inhibiting compounds which influenced the flame retardant behaviour of these samples during combustion. The intermetallic phase from the diffraction intensities showed the presence of a significant second bond interstitial solid-phase across the matrix, especially for ${ }_{0.6} \mathrm{Aldr}_{0.34} \mathrm{Cmt}_{0.05} \mathrm{G}_{0.01} \mathrm{OBS}$ ceiling material. Gaseous detection especially for $\mathrm{CO}$ began for $\mathbf{A} 1,{ }_{0.6} \mathrm{Aldr}_{0.3} \mathrm{Cmt}_{0.05} \mathrm{G}_{0.05} \mathrm{OBS}$ at $386^{\circ} \mathrm{C}$, a temperature well above room temperature, and at quasi post flashover room temperature fire. The temperature and non-detection of noxious emission at room temperature and up till $386^{\circ} \mathrm{C}$ established the suitability of the composited materials for building ceiling. For $\mathbf{A} 2,{ }_{10.6} \mathrm{Aldr}_{0.34} \mathrm{Cmt}_{0.05} \mathbf{G}_{0.01} \mathrm{OBS}, \mathrm{NO}_{x}$ rise depended on the $\mathrm{CO}$ detection at $300^{\circ} \mathrm{C}$. Negligible $\mathrm{SO}_{2}$ value faded when the temperature of the sample attained $300^{\circ} \mathrm{C}$. For $A 3,{ }_{0.6} \mathrm{Aldr}_{0.32} \mathrm{Cmt}_{0.05} \mathrm{G}_{0.03} \mathrm{UES}$, CO detection at 
$34^{\circ} \mathrm{C}$ was due to the nature of composition of the material structure of the developed sample. The low mass losses of all of the composite materials, especially for $\mathrm{A} 2,{ }_{0.6} \mathrm{Aldr}_{0.34} \mathrm{Cmt}_{0.05} \mathrm{G}_{0.01} \mathrm{OBS}$ retarded significantly due to its activities by the retardant constituent. Hence, the developed aluminium dross composites could be a good alternative to existing ceiling boards and for the manufacture of high-performance flame retardant ceiling materials.

\section{Declarations}

\section{Funding Statement}

This research did not receive any specific grants from funding agencies in the public, commercial, or not-for profit sectors thus no conflict of interest may emanate from these. The authors highly appreciate the contributions of Professor Esther Akinlabi, Department of Mechanical and Built Environment, University of Johannesburg, for the successful conduct of this research. E5500 gas analyzer and Thermolyne oven were provided by the Department of Mechanical and Built Environment, University of Johannesburg. Covenant University is recognized for the part sponsorship in conducting this research and publication supports.

\section{Author contributions}

Dr. Dirisu conceived and performed the analysis. Prof. Oyedepo and Dr. Fayomi guided in the data analysis; while Engr. Efenwenkiekie, Dr. Enesi, Prof. Asere and Prof.Oyekunle gave other contributions in the technicality of the writeup of this manuscript.

\section{Availability of Data and Material}

The authors confirmed that all data generated or analyzed during this study are included in this article.

\section{Compliance with ethical Standards}

The authors; Joseph Dirisu, Sunday Oyedepo, Ojo Fayomi Engr. Efenwenkiekie, Dr. Enesi, Prof. Asere and Prof.Oyekunle declare that they have NO affiliations with or involvement in any organization or entity with any financial interest (such as educational grants; participation in speakers' bureaus; membership, employment, consultancies, stock ownership, or other equity interest; and expert testimony or patent-licensing arrangements), or non-financial interest (such as personal or professional relationships, affiliations, knowledge or beliefs) in the subject matter or materials discussed in this manuscript.

\section{Consent to Participate}

The manuscript does not contain human as a subject and does not involve vulnerable group as a subject matter, so it is not applicable in this section.

\section{Consent for Publication}

The authors give consent for the publication of this manuscript in Silicon. The manuscript does not contain data of individual person, so there is no breach of privacy.

\section{References}


1. Bulle C, Margni M, Patouillard L, Boulay AM, Bourgault G, De Bruille V, Cao V, Hauschild M, Henderson A, Humbert $S$, Kashef-Haghighi S. IMPACT World+: a globally regionalized life cycle impact assessment method. The International Journal of Life Cycle Assessment. 2019 Sep 1;24(9):1653-74.

2. Adeodu A, Mudashiru L, Daniyan I, Awodoyin A. Effect of silver nanoparticle (AgNp) mixed with calcium carbonate on impact, hardness and tensile strength properties of aluminium 6063. Journal of Composite Materials. 2020 May 4:0021998320923141.

3. Dietsch P, Winter S. Structural failure in large-span timber structures: a comprehensive analysis of 230 cases. Structural safety. 2018 Mar 1;71:41-6.

4. Wang P, Cai Z. Highly efficient flame-retardant epoxy resin with a novel DOPO-based triazole compound: Thermal stability, flame retardancy and mechanism. Polymer Degradation and Stability. 2017 Mar 1;137:138-50.

5. Jin S, Qian L, Qiu Y, Chen Y, Xin F. High-efficiency flame retardant behavior of bi-DOPO compound with hydroxyl group on epoxy resin. Polymer Degradation and Stability. 2019 Aug 1;166:344-52.

6. Hejna A, Kosmela P, Kirpluks M, Cabulis U, Klein M, Haponiuk J, Piszczyk $Ł$. Structure, mechanical, thermal and fire behavior assessments of environmentally friendly crude glycerol-based rigid polyisocyanurate foams. Journal of Polymers and the Environment. 2018 May 1;26(5):1854-68.

7. Dirisu JO, Fayomi OS, Oyedepo SO, Jolayemi KJ, Moboluwarin DM. Critical evaluation of aluminium dross composites and other potential building ceiling materials. Procedia Manufacturing. 2019 Jan 1;35:1205-10. Mahinroosta M, Allahverdi A. Hazardous aluminum dross characterization and recycling strategies: A critical review. Journal of environmental management. 2018 Oct 1;223:452-68.

8. Samat N, Sabaruddin FA, Yusoff MM, Habibah AD. Evaluation of waste from aluminum industry as filler in polypropylene composites. JOM. 2017 Apr 1;69(4):790-5.

9. Mohajerani A, Suter D, Jeffrey-Bailey T, Song T, Arulrajah A, Horpibulsuk S, Law D. Recycling waste materials in geopolymer concrete. Clean Technologies and Environmental Policy. 2019 Apr 15;21(3):493-515.

10. Akçaözoğlu K, Akçaözoğlu S. The Effect of Elevated Temperature on the Lightweight Concrete Produced by Expanded Clay Aggregate and Calcium Aluminate Cement. Bilge International Journal of Science and Technology Research. 2017;1(2):59-70.

11. Sufian AS, Samat N, Sulaiman MY, Paulus W. Alumina Recovery from Industrial Waste: Study on the Thermal, Tensile and Wear Properties of Polypropylene/Alumina Nanocomposites. International Journal of Precision Engineering and Manufacturing-Green Technology. 2020 Jan 1;7(1):163-72.

12. Sanni O, Fayomi OS. The inhibitive study of egg shell powder on uns n08904 austenitic stainless steel corrosion in chloride solution. Defence Technology. 2018 Oct 1;14(5):463-8.

13. Sanni O, Fayomi OS. Temperature Effect, Activation Energies and Adsorption Studies of Waste Material as Stainless Steel Corrosion Inhibitor in Sulphuric Acid 0.5 M. Journal of Bio-and Tribo-Corrosion. 2019 Dec $1 ; 5(4): 88$.

14. Dirisu JO, Oyedepo SO, Fayomi OS. Thermal energy assessment of oil bean stalk as a novel additive to building ceilings. InAIP Conference Proceedings 2019 Dec 11 (Vol. 2190, No. 1, p. 020076). AIP Publishing LLC.

15. Inegbenebor AO, Fayomi OS, Joshua O, Jolayemi KJ, Inegbenebor Al, Joseph OO. Assessment of Some Clay South West and Aluminmium Dross as Roofing Tile Materials. InIOP Conference Series: Materials Science and Engineering $2018 \mathrm{Jul}$ (Vol. 391, No. 1, p. 012009). IOP Publishing.

16. Ogunyemi, S. A., Ajileye, O. O., Muibi, K. H., Alaga, A. T., Eguaroje, O. E., Samson, S. A., ... \& Omisore, O. O. (2017). Geo-Information and Distribution Pattern of Petrol Service Station in Sango-Ota Metropolis in Ado-Odo Ota Local Government Area, Ogun State, Nigeria. Asian Research Journal of Arts \& Social Sciences, 1-11. 
17. Popoola SI, Atayero AA, Arausi OD, Matthews VO. Path loss dataset for modeling radio wave propagation in smart campus environment. Data in brief. 2018 Apr 1;17:1062-73.

18. Gnyrya, A., Abzaev, Y., Korobkov, S., Mokshin, D., Gauss, K., \& Boyarintsev, A. (2017, November). High-temperature structure formation in cement depending on curing In AIP Conference Proceedings.1899 (1), 040005.

19. Go, Y., Jo, S. M., Park, S. H., Kim, H. S., You, B. S., \& Kim, Y. M. (2018). Microstructure and mechanical properties of non-flammable Mg-8Al-0.3 Zn-0.1 Mn-0.3 Ca-0.2 Y alloy subjected to low-temperature, low-speed extrusion. Journal of Alloys and Compounds, 739, 69-76.

20. Gneiger, S., Papenberg, N., Frank, S., \& Gradinger, R. (2018, March). Investigations on microstructure and mechanical properties of non-flammable Mg-Al-Zn-Ca-Y In TMS Annual Meeting \& Exhibition. Springer, Cham, 105-113.

21. Maruta, K., Tsuboi, K., \& Takahashi, S. (2017). Limiting oxygen concentration of flame resistant material in microgravity environment. Int J Microgravity Sci Appl, 34(3),

22. Davis, L. B., Saxen, M. A., Jones, J. E., McGlothlin, J. D., Yepes, J. F., \& Sanders, B. J. (2018). The Effects of different levels of ambient oxygen in an oxygen-enriched surgical environment and production of surgical fires.Anesthesia progress,65(1),3-8.

23. Li, J., \& Chang, J. (2019). Effect of crystal/amorphous ratio on mechanical properties in a C4A3 \$-C2S hydration system with or without gypsum addition. Construction and Building Materials, 208, 36-45.

24. Rejmak, P., Dolado, J. S., Aranda, M. A., \& Ayuela, A. (2019). First-Principles Calculations on Polymorphs of Dicalcium Silicate-Belite, a Main Component of Portland Cement. The Journal of Physical Chemistry C, 123(11), 6768-6777.

25. Zhang, Y., Rimstidt, D. J., Huang, Y., \& Zhu, C. (2019). Kyanite far from equilibrium dissolution rate at $0-22^{\circ} \mathrm{C}$ and $\mathrm{pH}$ of 3.5-7.5. Acta Geochimica, 38(4), 472-480.

26. Shevchenko, V. Y., Medrish, I. V., Ilyushin, G. D., \& Blatov, V. A. (2019). From clusters to crystals: scale chemistry of intermetallics. Structural Chemistry, 1-13.

27. Jose, S., Shanmugam, N., Das, S., Kumar, A., \& Pandit, P. (2019). Coating of lightweight wool fabric with nano clay for fire retardancy. The Journal of the Textile Institute, 110(5), 764-770.

28. Yang, F. (2017). Fire-retardant carbon-fiber-reinforced thermoset composites. In Novel Fire Retardant Polymers and Composite Materials (pp. 271-293). Woodhead Publishing.

29. Jin, J., Long, Y., Gao, H., \& Ren, Z. (2019). Flotation behavior and mechanism of andalusite and kyanite in the presence of sodium oleate. Separation Science and Technology, 54(11), 1803-1814.

30. Drysdale, D. (2011). An introduction to fire dynamics. John Wiley \& Sons.

31. Sharma, G., Sinha, B., Hakkim, H., Chandra, B. P., Kumar, A., \& Sinha, V. (2019). Gridded Emissions of CO, NOQ,

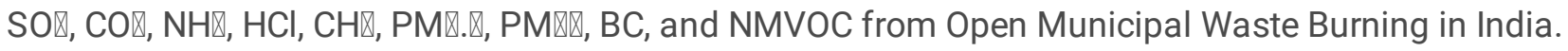

Environmental science \& technology.

32. Winkler, H. C., Notter, T., Meyer, U., \& Naegeli, H. (2018). Critical review of the safety assessment of titanium dioxide additives in food. Journal of nanobiotechnology, 16(1), 51.

33. Tranchida, D., Gloger, D., \& Gahleitner, M. (2017). A critical approach to the Kissinger analysis for studying nonisothermal crystallization of polymers. Journal of Thermal Analysis and Calorimetry, 129(2), 1057-1064.

34. Kiselev, E. G., Kuzmin, A. P., \& Nemtsev, I. V. (2019). Thermal and Mechanical Studies of Biofiller/Poly-3Hydroxybutyrate Biocomposites. Journal of Siberian Federal University. Biology, 12(3), 302-310. 
35. Weber J, Schlimbach J. Co-consolidation of CF/PEEK tape-preforms and CF/PEEK organo sheets to manufacture reinforcements in stamp-forming process. Advanced Manufacturing: Polymer \& Composites Science. 2019 Oct 2;5(4):172-83

\section{Figures}

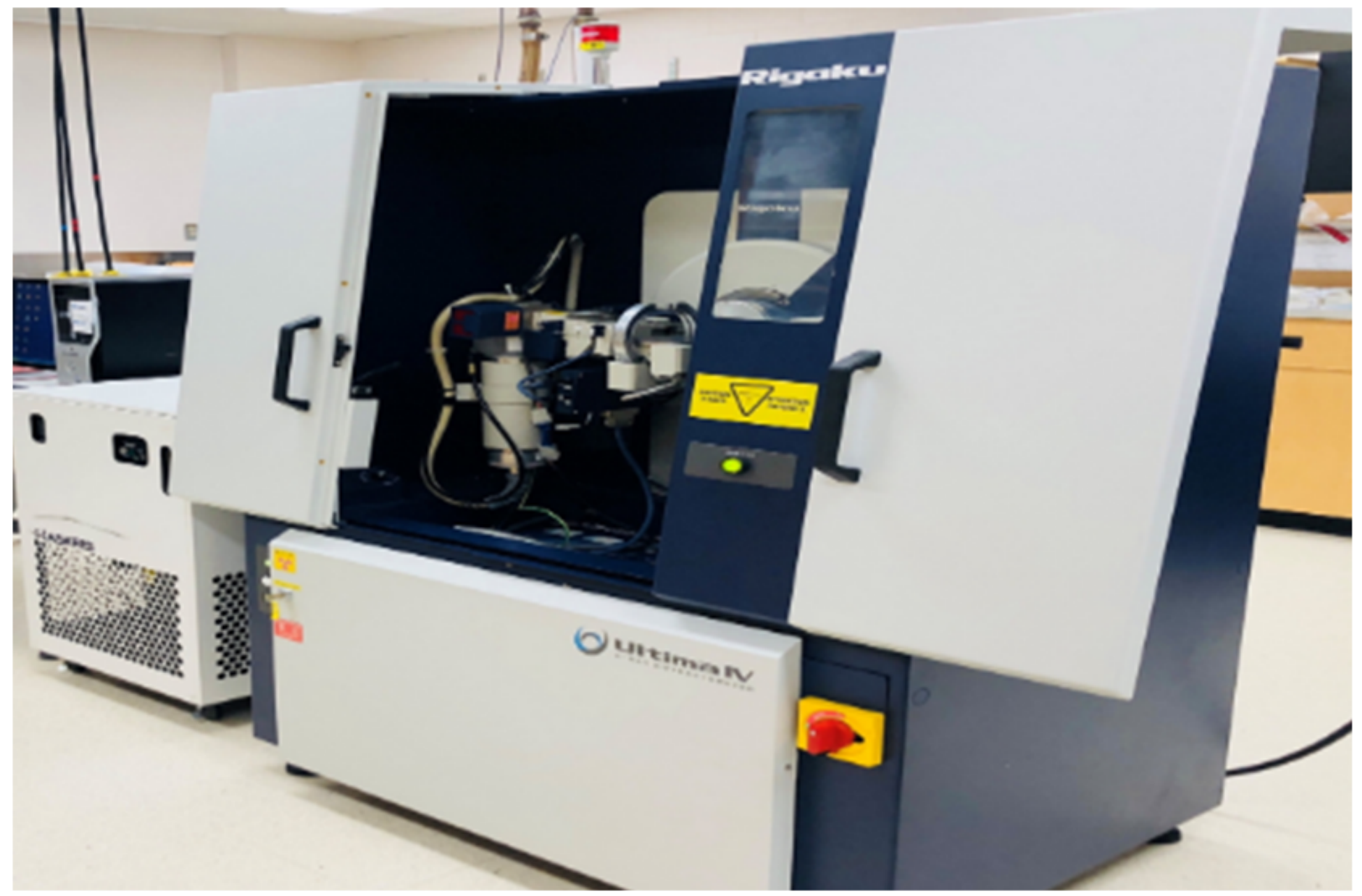

\section{Figure 1}

Rigaku X-ray diffractometer 


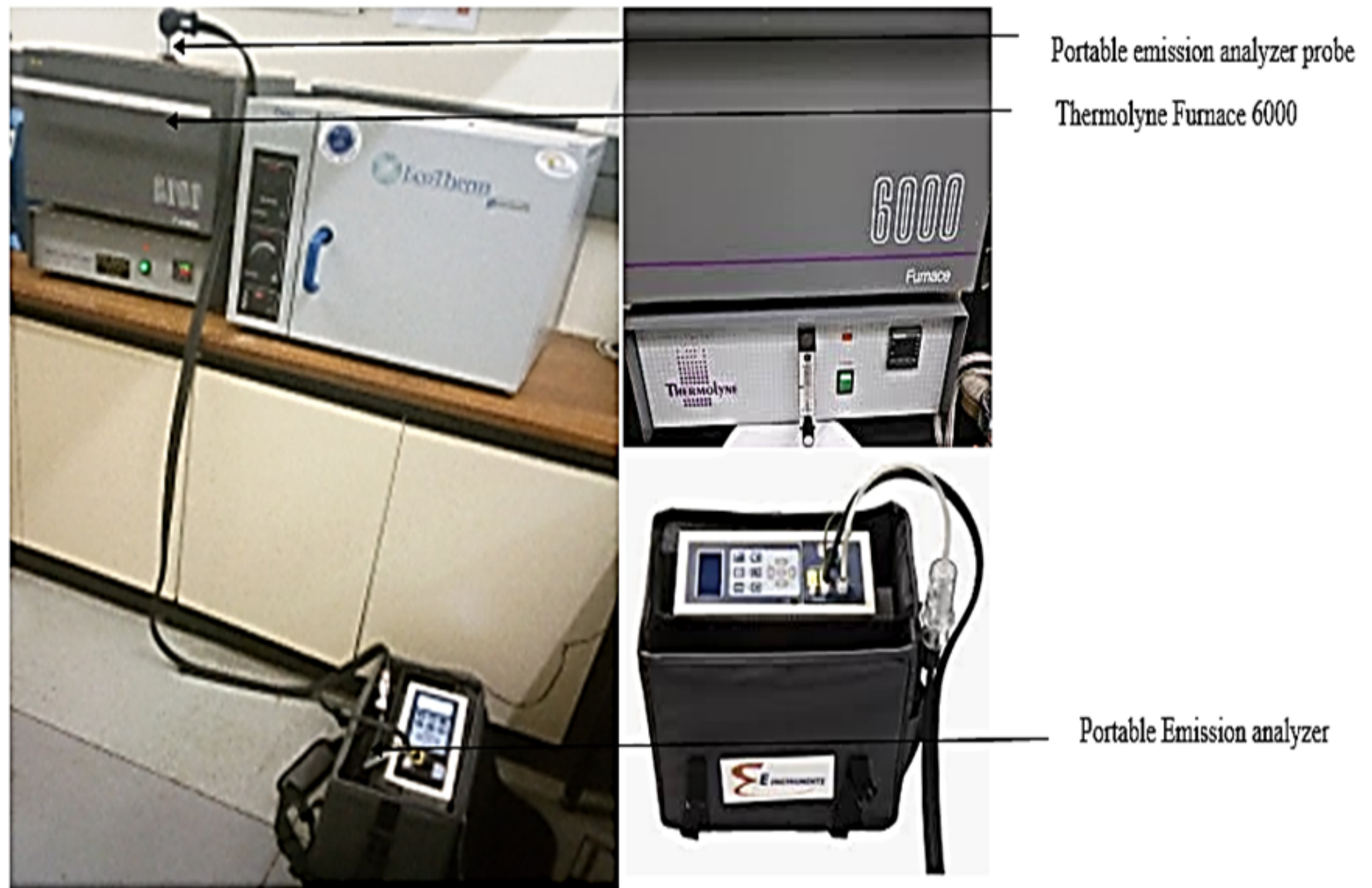

Figure 2

Portable Emission analyzer and 950oC Thermolyne Oven

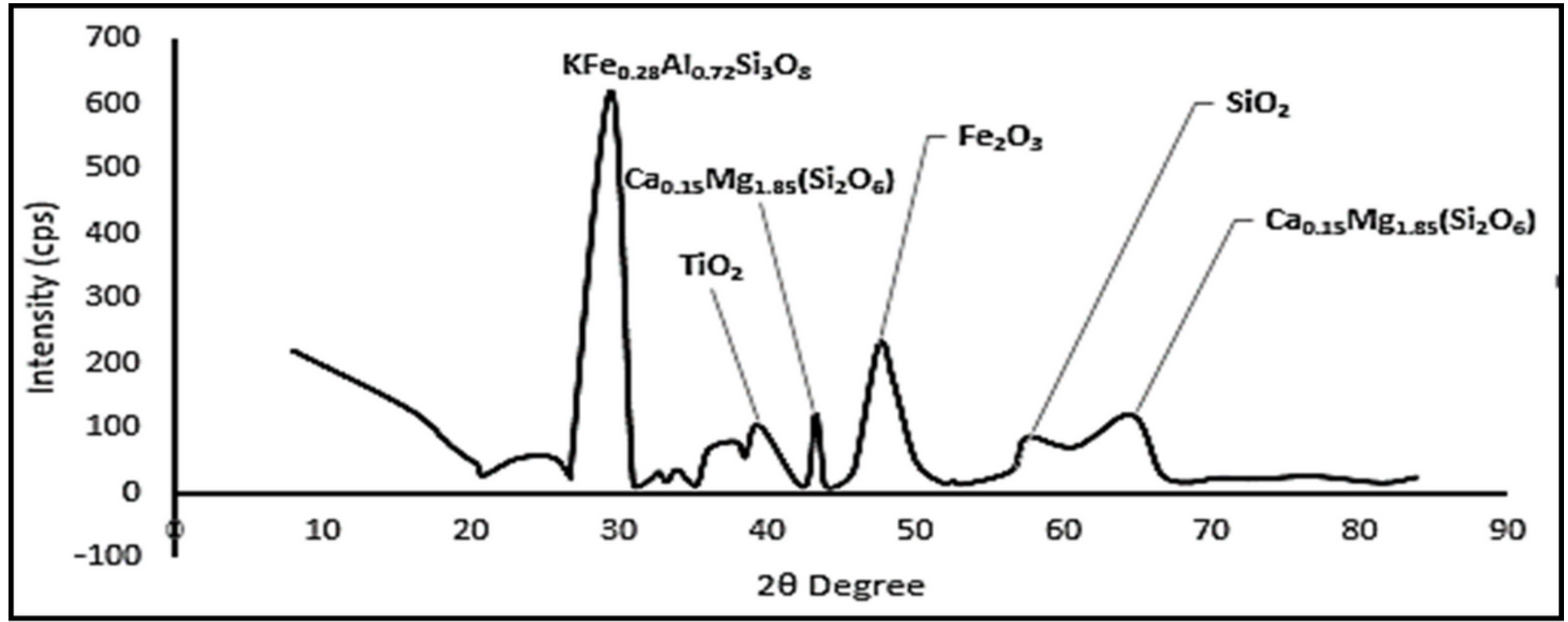

Figure 3

XRD peak point for $\mathrm{A} 1,0.6 \mathrm{Aldr0} .3 \mathrm{Cmt} 0.05 \mathrm{G} 0.050 \mathrm{BS}$ 


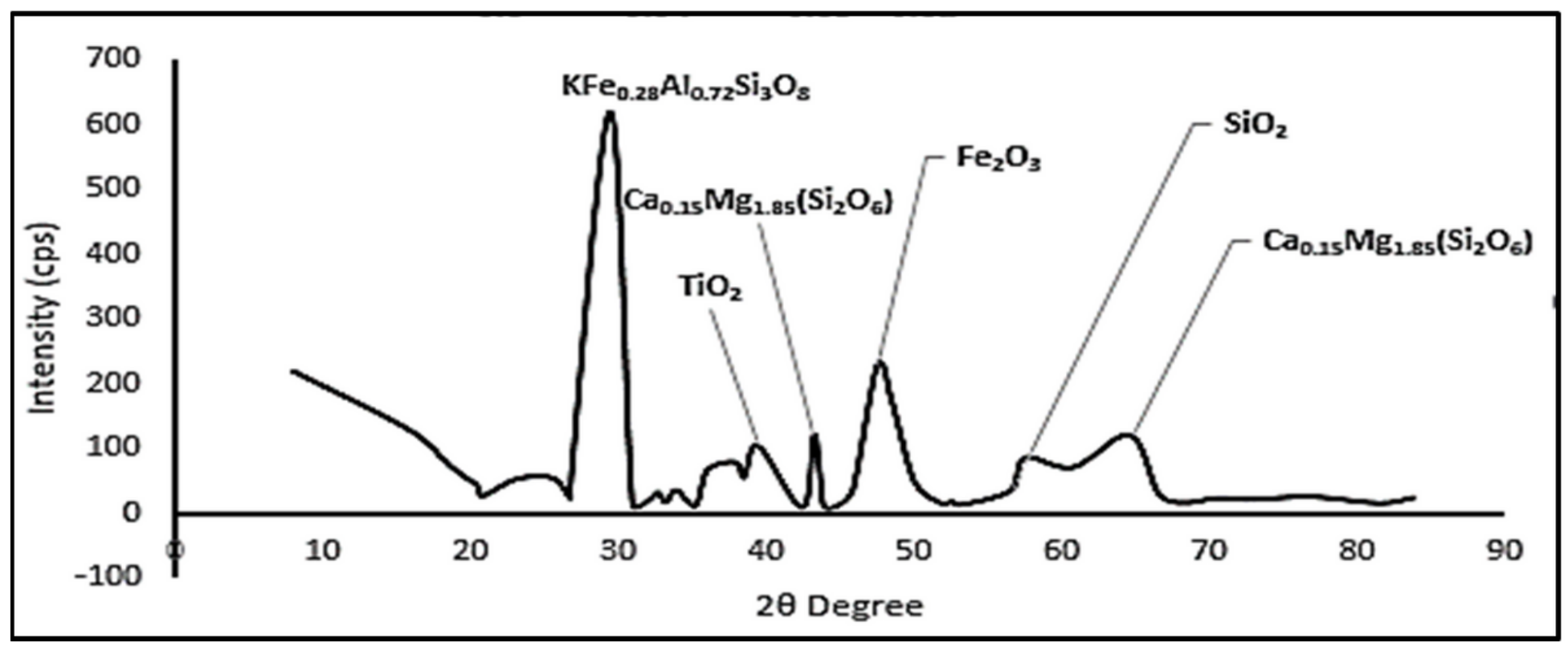

Figure 4

XRD peak point for A2,0.6Aldr0.34Cmt0.05G0.010BS

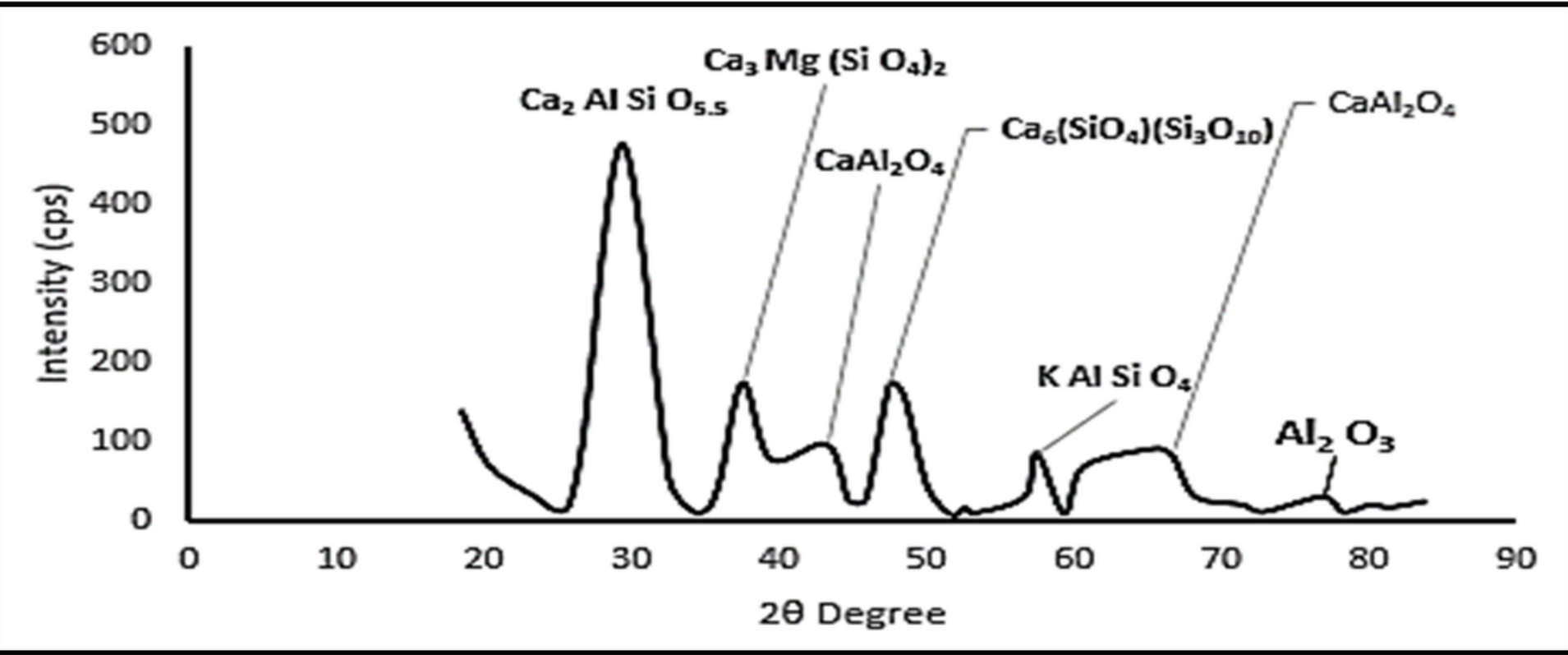

Figure 5

XRD peak point for A30.6Aldr0.32Cmt0.05G0.03UES 


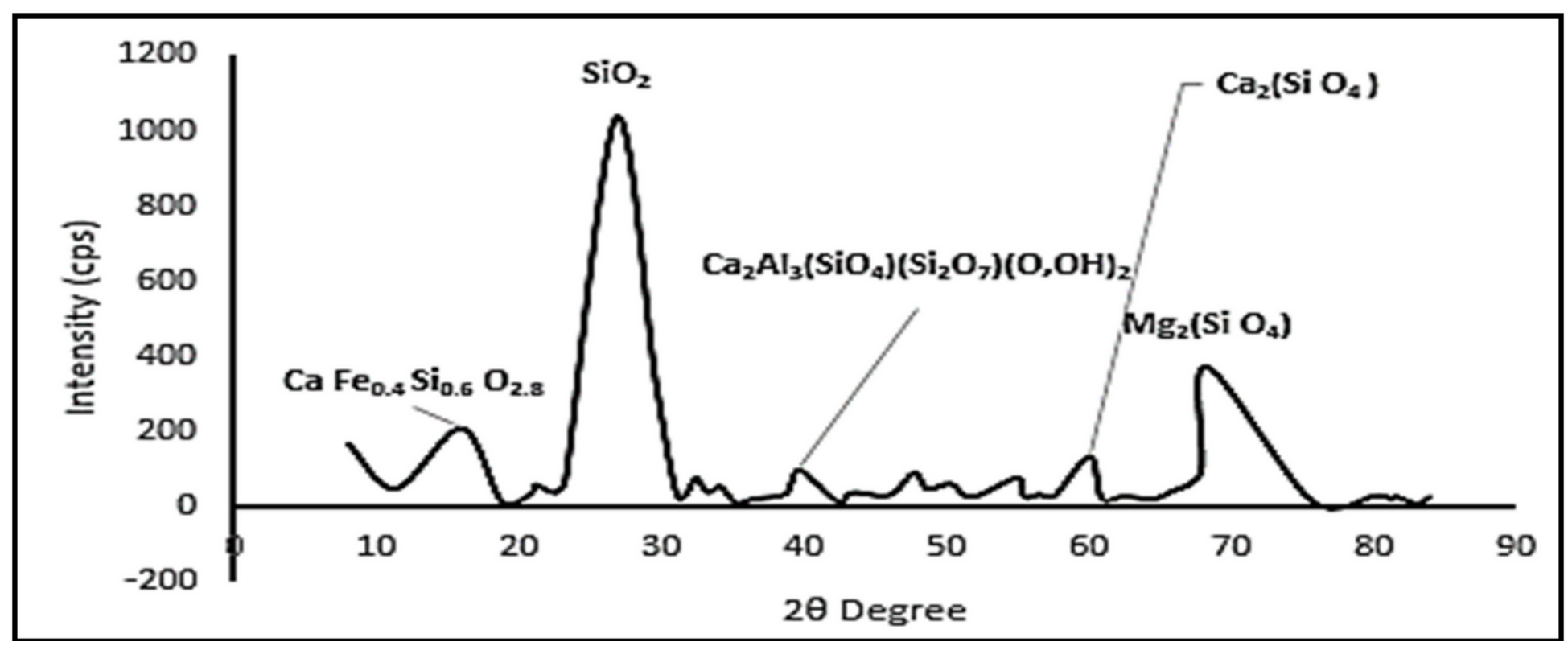

Figure 6

XRD peak point for A40.3Aldr0.23Cmt0.3Si0.05G0.12CS

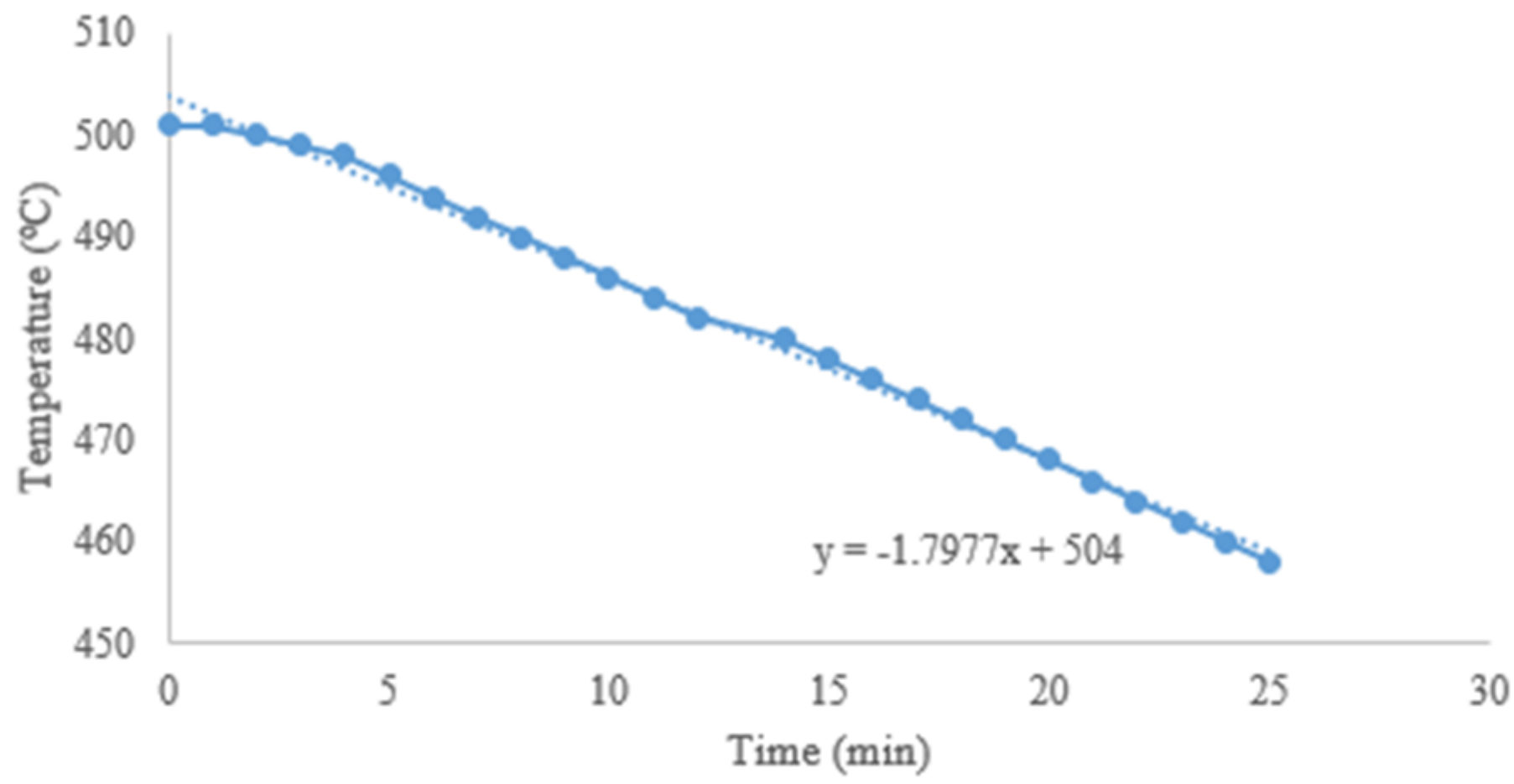

Figure 7

Cooling rate after combustion, A1 


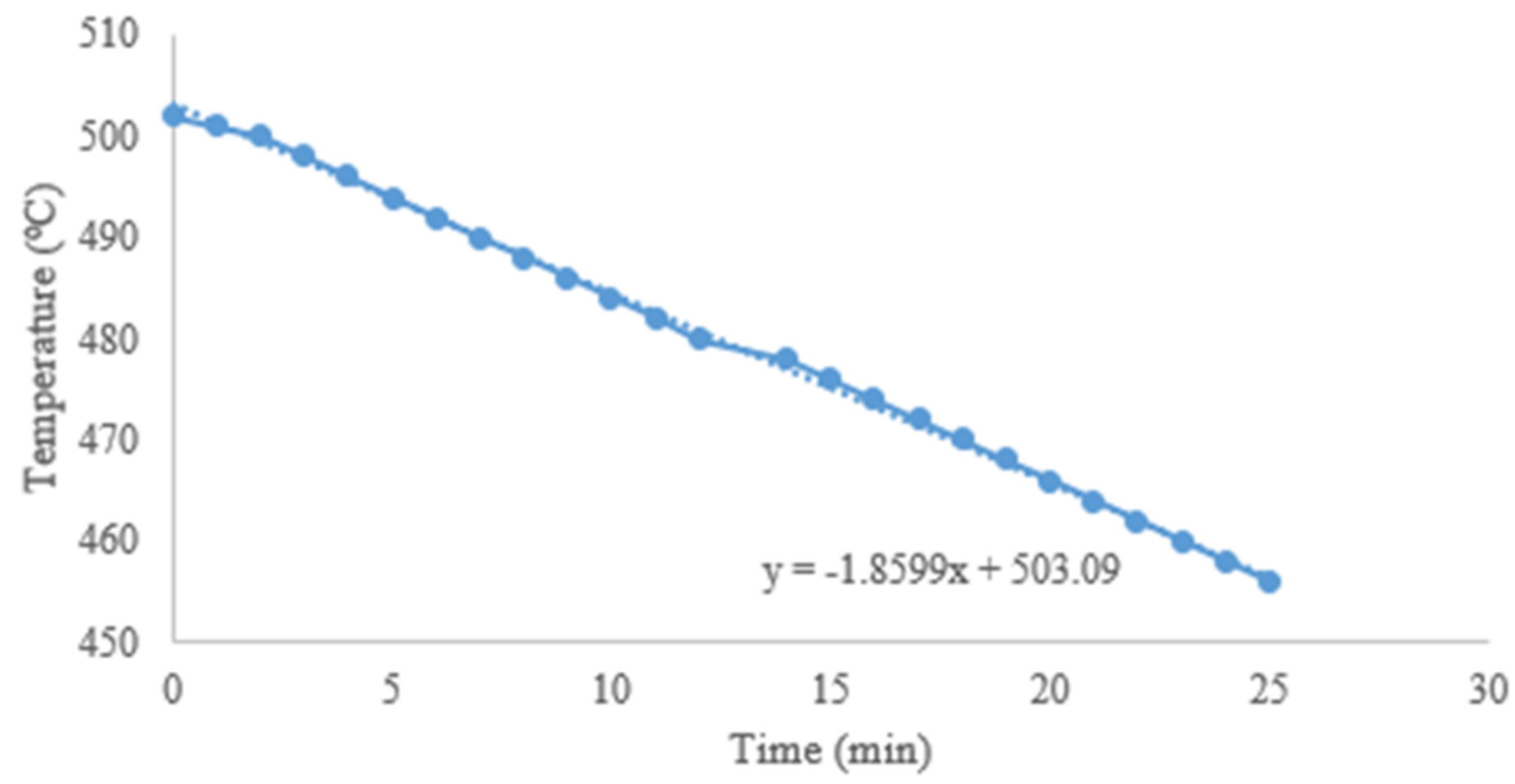

Figure 8

Cooling rate after combustion, $\mathrm{A} 2$

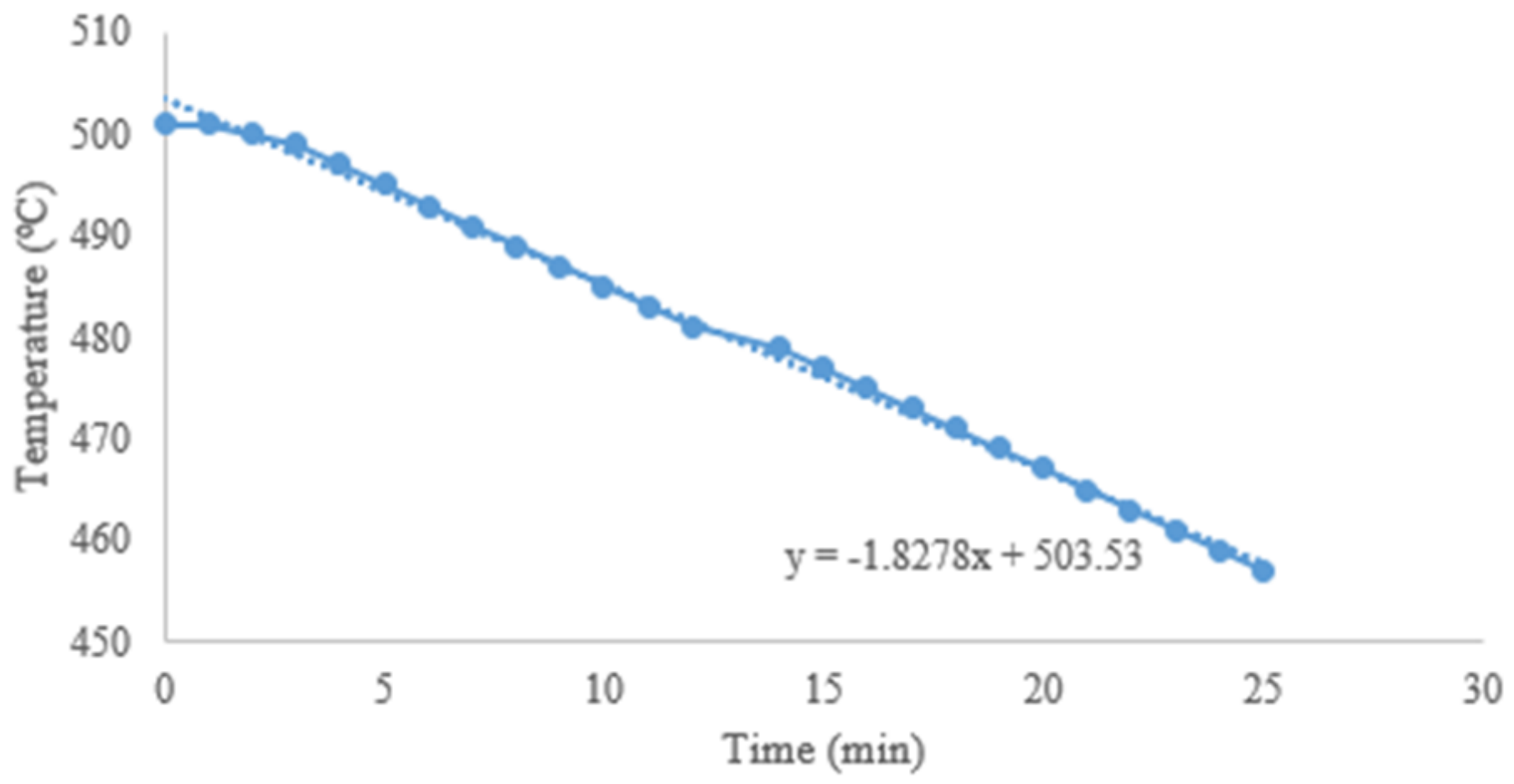

Figure 9

Cooling rate after combustion, $\mathrm{A} 3$ 


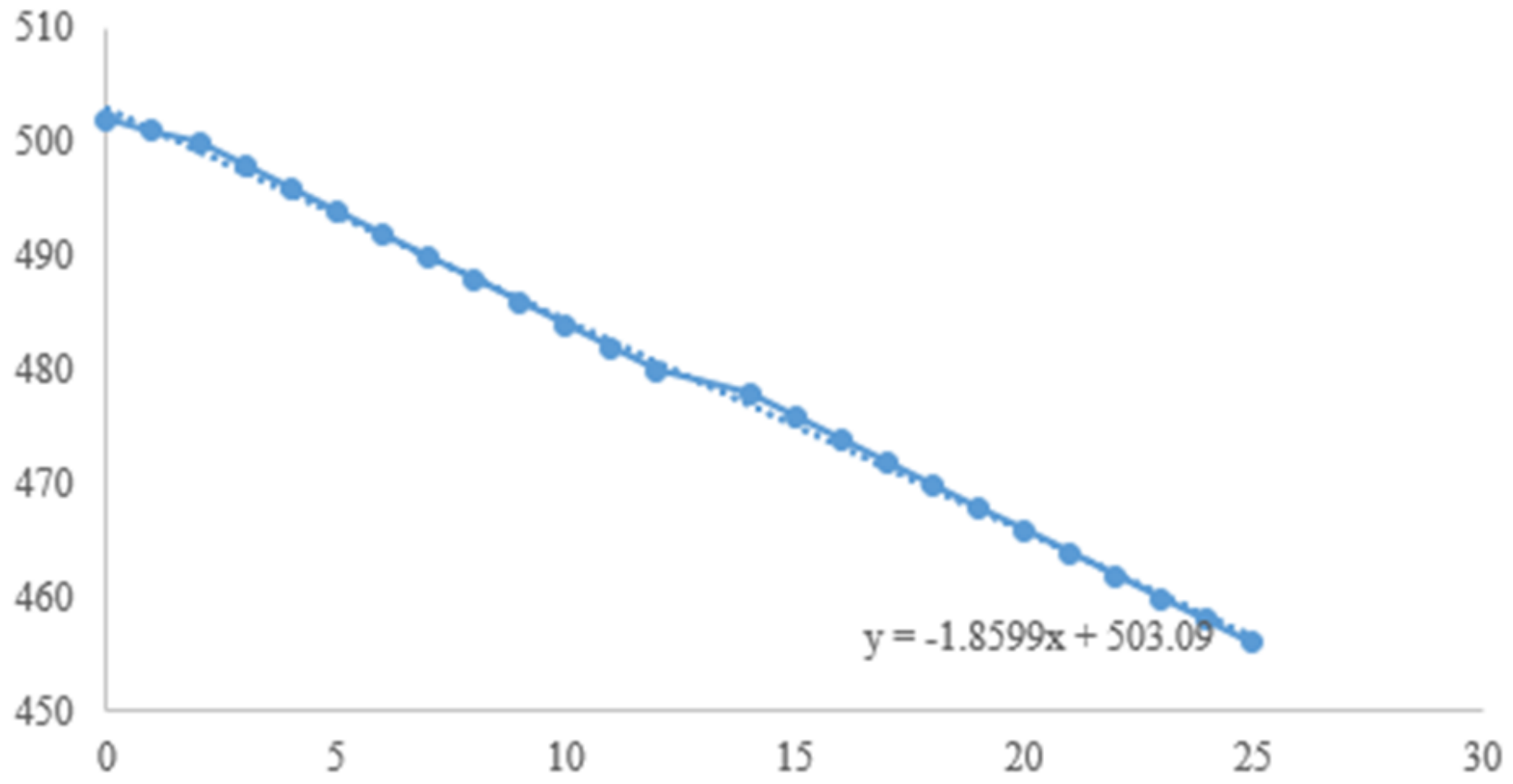

Figure 10

Cooling rate after combustion, A4

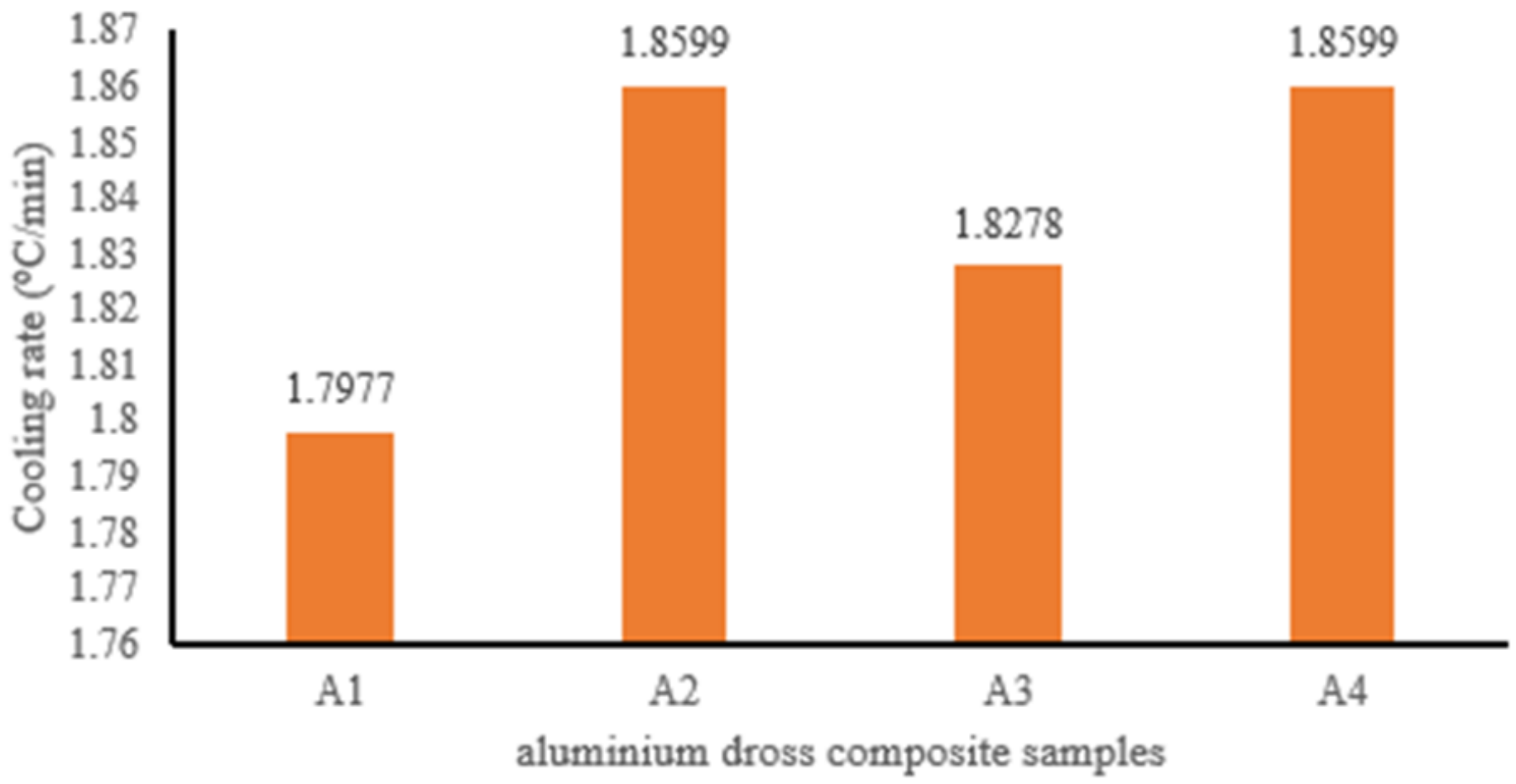

Figure 11

Comparison of cooling rate among composite samples 


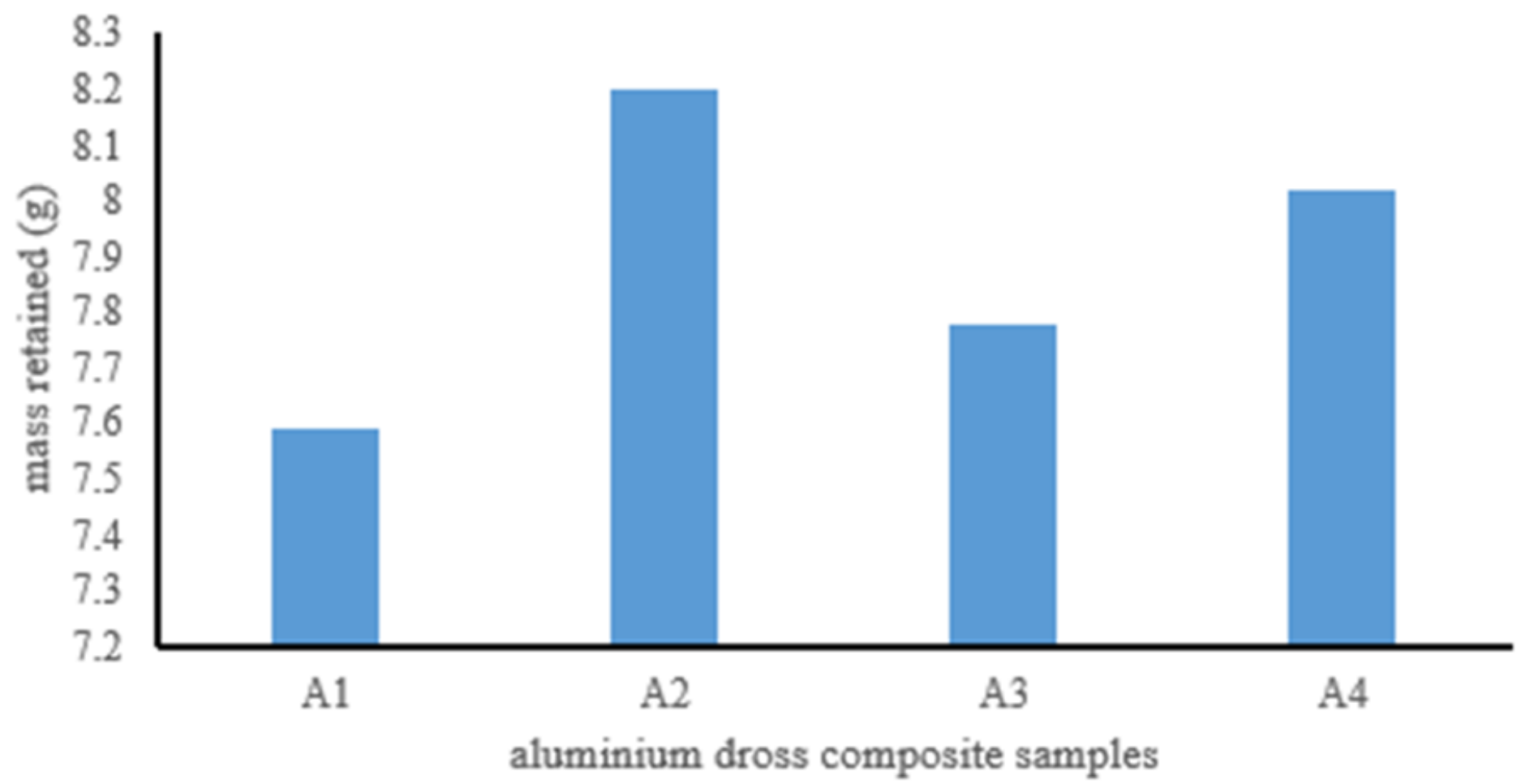

Figure 12

Mass of Composite Samples retained after Combustion

\section{Supplementary Files}

This is a list of supplementary files associated with this preprint. Click to download.

- AppendixA.docx 